\title{
Cold-hardiness, Acclimation, and Deacclimation among Diverse Blueberry Genotypes
}

\author{
Mark K. Ehlenfeldt ${ }^{1}$ \\ U.S. Department of Agriculture, Agricultural Research Service, Genetic Improvement of Fruits \\ and Vegetables Laboratory, at Marucci Center for Blueberry and Cranberry Research and Extension, \\ 125A Lake Oswego Road, Chatsworth, NJ 08019
}

Lisa J. Rowland and Elizabeth L. Ogden

U.S. Department of Agriculture, Agricultural Research Service, Henry A. Wallace Beltsville Agricultural Research Center, Genetic Improvement of Fruits and Vegetables Laboratory, Building 010A, BARC-West, Beltsville, MD 20705

\author{
Bryan T. Vinyard \\ U.S. Department of Agriculture, Agricultural Research Service, Henry A. Wallace Beltsville \\ Agricultural Research Center, Biometrical Consulting Service, Building 005, BARC-West, Beltsville, \\ MD 20705
}

\begin{abstract}
AdDitional INDEX words. hardening, dehardening, freezing tolerance, Vaccinium
Abstract. Cold injury to plants can occur by early fall freezes before cold acclimation, by severe midwinter freezes that exceed the limits of the plant's tolerance, or by hard freezes in late winter or early spring after partial or complete deacclimation. Ideally, blueberry (Vaccinium L.) cultivars for temperate regions should acclimate to cold quickly in the fall, have a high midwinter-hardiness, and deacclimate late and/or slowly during spring or during unseasonably warm spells in winter, and do all of this without adversely delaying time of fruiting. Until recently, only limited evaluations have been done on the acclimation and deacclimation process in blueberry, although it is an integral part of flower bud survival and, thus, is directly related to potential yield. In this study, we have measured the timing and rate of acclimation and deacclimation in seven blueberry genotypes with different amounts of diverse species germplasm in their backgrounds. Primary differences observed among the seven genotypes were differences in maximum hardiness levels and the date at which they were reached, and differences in the date at which maximum acclimation levels were no longer sustained and deacclimation started. Highbush cultivars Bluecrop and Legacy $(V$. corymbosum L.), rabbiteye cultivar Tifblue $[V$. ashei Reade (= V. virgatum Aiton)], and two rabbiteye hybrid derivatives (US 1043 and US 1056) all reached maximum or near maximum cold-hardiness by late December with temperatures causing $50 \%$ lethality $\left(\mathrm{LT}_{50}\right)$ in a range from -22 to $-27^{\circ} \mathrm{C}$. The half-high, 'Northsky', and a hybrid of $V$. constablaei Gray $\times V$. ashei 'Little Giant' both achieved cold acclimation of $-28^{\circ} \mathrm{C}$ or below (the lowest value we could measure) by the end of November. After reaching their maximum hardiness in late December, 'Legacy', 'Tifblue', and US 1043 began a sustained and relatively linear deacclimation, whereas US 1056, 'Bluecrop', 'Northsky', and 'Little Giant' sustained their acclimation for longer intervals. 'Bluecrop' and US 1056 did not begin to deacclimate until early March, and 'Little Giant' and 'Northsky' had no $\mathbf{L T}_{50}$ values higher (warmer) than $-25^{\circ} \mathrm{C}$ until late March. As concerns about climate change increase, knowledge of the ability of breeding germplasm to tolerate greater temperature extremes and fluctuations will prove increasingly valuable.
\end{abstract}

There are over 60,000 ha of cultivated blueberries in North America (Ballington, 2001; Trinka, 1996), and the United States is the world's leading producer. In a survey of blueberry research and extension scientists in the United States, lack of winterhardiness and susceptibility to spring frosts have been identified as two of the most important problems of current cultivars (Moore, 1993), and in the northern blueberry production areas, winter damage is considered the major factor limiting yields (Hanson and Hancock, 1990; Moore, 1994). In nearly all blueberry growing areas in the United States, economic losses from early spring frosts can be significant.

Deacclimation response is an important part of reproductive success in woody perennials because late winter or early spring warm spells followed by hard freezes can cause severe injury to dehardened flower buds. Ideally, blueberry cultivars for the

Received for publication 16 Sept. 2011. Accepted for publication 1 Dec. 2011. ${ }^{1}$ Corresponding author. E-mail: mark.ehlenfeldt@ars.usda.gov.
United States should deacclimate slowly and deacclimate later during spring, thus avoiding the perils of unseasonable warm spells in late winter and do this without adversely delaying the time of fruiting. Acclimation in woody perennials is perhaps less critical than deacclimation because acclimation is a steady, incremental process, and sharp freezes exceeding a plant's cold tolerance are rare events that may affect only less mature tissue. Nonetheless, idealized acclimation would be a rapid acclimation response once the necessary environmental trigger was reached and would be consistent and uniform from year to year. Triggers for acclimation and deacclimation vary among woody perennials. Bittenbender and Howell (1975), using six highbush blueberry cultivars adapted to Michigan conditions, consistently found the highest correlation of flower bud hardiness with photoperiod (average $r=0.94$ across fall-winter-spring) and to a slightly lesser degree with air temperature (average $r=0.75$ ). In contrast, deacclimation and dormancy transitions in another woody plant, mountain birch (Betula pubescens Ehrh.), were 
found to be modulated mainly by temperature and not photoperiod (Welling et al., 2004).

Maximum cold-hardiness in midwinter is affected by the plant's growth cycle and fall conditions, including temperatures and rainfall (Bittenbender and Howell, 1975). In a previous study, the highbush blueberry cultivar Legacy was observed to have $\mathrm{LT}_{50}$ minima varying by as much as $6^{\circ} \mathrm{C}$, presumably as a result of year-to-year differences in fall temperature conditions (Rowland et al., 2005). Similarly, Hanson et al. (2007) assessed cold-hardiness, acclimation, and deacclimation of several blueberry cultivars over 2 years and documented differences in cold-hardiness averaging $\approx 8{ }^{\circ} \mathrm{C}$ between years. Other studies have noted that late-season fertilization can spur vegetative growth and can result in wintertime shoot damage as a result of lack of acclimation (Brierley and Hildreth, 1928; Gough, 1994).

In a previous study, we measured the bud cold-hardiness of fully cold-acclimated plants among diverse cultivars and examined the deacclimation of these cultivars under field conditions (Rowland et al., 2005). Observations over a 7 -week period in 2 consecutive years revealed clear genotypic differences in coldhardiness levels of fully acclimated plants and in timing and rate of deacclimation. These studies revealed extreme cold-hardiness in $V$. constablaei and some $V$. constablaei derivatives as well as relatively low cold-hardiness of some southern highbush cultivars such as Legacy. Deacclimation rates were not correlated with midwinter hardiness or chilling requirements, and a strong positive correlation was found between bud cold-hardiness and stage of bud opening $(r=0.84)$. Observations of the timing of deacclimation indicated that $V$. constablaei was particularly late to deacclimate, and 'Little Giant', a 50:50 hybrid of $V$. constablaei and $V$. ashei, was nearly as late to deacclimate as pure $V$. constablaei. Thus, $V$. constablaei was posited as potentially useful in breeding programs to contribute genes for midwinterhardiness as well as genes for late deacclimation, both of which should translate into greater spring frost tolerance.

This study was undertaken to investigate cold-hardiness and acclimation/deacclimation rates and phenologies under field conditions for seven blueberry genotypes with complex germplasm compositions and different expected midwinter bud hardiness levels.

\section{Materials and Methods}

Plant material. The germplasm compositions of the genotypes used are given in Table 1. Germplasm composition of named cultivars was determined using previously published information (Ehlenfeldt, 1994; Hancock and Siefker, 1982). The seven blueberry genotypes used for this study were: 'Bluecrop' (northern highbush), 'Legacy' (southern highbush), 'Little Giant' (coldhardy $V$. constablae $\times$ rabbiteye hybrid), 'Northsky' (half-high),
'Tifblue' (rabbiteye), and two rabbiteye-hybrid derivatives, US 1043 and US 1056. US 1043 and US 1056 are complex $V$. asheil $V$. constablaei derivatives selected from a breeding project designed to develop cold-hardy rabbiteye-type plants and have previously been evaluated for midwinter floral bud cold-hardiness (Ehlenfeldt et al., 2007). In total, these seven genotypes represent a wide range of midwinter flower bud hardiness as determined from previous studies (Ehlenfeldt et al., 2007; Muthalif and Rowland, 1994; Rowland et al., 2008). Species composition was categorized broadly into cold-hardy germplasm and cold-sensitive germplasm. Based on their native habitat and previous experimentation, $V$. constablaei and $V$. angustifolium Ait. are expected to be the most cold-hardy followed by $V$. corymbosum, $V$. darrowii Camp, V. tenellum Ait., and $V$. ashei in general order of decreasing cold-hardiness. $V$. constablaei is a highbush-like hexaploid species that, although native to the southern regions of the United States, is found at high elevations in northern Georgia, western North Carolina, and eastern Tennessee. V. corymbosum and $V$. angustifolium are tetraploid highbush and lowbush species, respectively, native to a wide range of temperate areas of the eastern third of North America. The diploid lowbush species, $V$. darrowii and $V$. tenellum, and the hexaploid species, $V$. ashei (rabbiteye), are all native to the southern United States.

Shoots of all samples came from mature plants in experimental plantings at the P.E. Marucci Center for Blueberry and Cranberry Research and Extension (Rutgers University) in Chatsworth, NJ. All plants for shoot collection were at least 4-5 years old. Shoots were cut from different numbers of plants of each genotype as follows: 'Bluecrop' (five), 'Legacy' (five), 'Little Giant' (five), 'Northsky' (two), 'Tifblue' (two), US 1043 (one), and US 1056 (one). We strove for as much uniformity as possible when sampling the shoots. Samples were generally from terminal shoots taken from upper portions of the bush where they would have been above the snow line (a critical concern particularly when sampling half-highs). 
DETERMINATION OF FLOWER-BUD COLD-HARDINESS. Detached shoots were assayed in 2006-2007 and in 2007-2008 to determine flower bud cold-hardiness and timing and rate of acclimation and deacclimation. In 2006-2007, detached shoots were assayed from 17 Oct. (Week 3) through 11 Apr. (Week 28); in 2007-2008, an earlier starting date was used for the three coldhardiest cultivars (Bluecrop, Northsky, and Little Giant) adding one sampling date and covering a period from 26 Sept. (Week 0) through 9 Apr. (Week 28). Beyond this additional early sampling, all remaining sampling dates matched the previous year within a range of 1-2 d. Sampling was done at 3-week intervals in both years, except for three consecutive samplings from 10 Jan. to 27 Mar. that were done at intervals of 4, 4, and 2 weeks (see Table 2).

Five- to 6-cm-long shoots with three to eight flower buds were subjected to a freeze-thaw protocol that consisted of placing three randomly sampled shoots/treatment temperature from each genotype in test tubes (three shoots/tube) with $0.5 \mathrm{~mL}$ of water and subjecting them to controlled freezing in a glycol bath (Model 2325; Forma Scientific, Marietta, $\mathrm{OH}$ ) for each sampling date. Bud temperature was monitored by copper-constantan thermocouples (TT-T-30) attached to a thermometer (DP465; Omega Engineering, Stamford, CT). Ice nucleation was initiated at $-1{ }^{\circ} \mathrm{C}$. Samples were allowed to equilibrate for $\approx 45 \mathrm{~min}$ at $-1{ }^{\circ} \mathrm{C}$ and then further cooled at $0.5^{\circ} \mathrm{C} / 30 \mathrm{~min}$ down to $-4{ }^{\circ} \mathrm{C}$, at $1{ }^{\circ} \mathrm{C} / 30 \mathrm{~min}$ down to $-8^{\circ} \mathrm{C}$ and at $2{ }^{\circ} \mathrm{C} / 30$-min intervals thereafter to respective final treatment temperatures. Initial treatment temperatures covered a range from -5 to $-28{ }^{\circ} \mathrm{C}$ (the lowest temperature that the glycol freezing bath would consistently reach) at $2{ }^{\circ} \mathrm{C}$ increments to cover a $0 \%$ to $100 \%$ injury range of blueberry flower buds for most genotypes (Arora et al., 1997). Shoots were removed from the freezing bath at respective treatment temperatures, thawed overnight at $4{ }^{\circ} \mathrm{C}$, and incubated at $20{ }^{\circ} \mathrm{C}$ for $24 \mathrm{~h}$. Subsequently, the three most distal buds were dissected and observed for injury (visual browning of the inflorescence primordia in individual flowers) (Arora et al., 2000; Flinn and Ashworth, 1994). Each bud was rated for percentage of injured ovaries and an overall percent injury was determined for each shoot. Buds were scored for damage across temperature treatments until all buds at two consecutively lower temperatures exhibited $100 \%$ damage.

After initial trials, and as the buds acclimated, the treatment temperature ranges between the samplings of frozen buds were adjusted and refined to appropriate starting and ending temperatures to bracket the $\mathrm{LT}_{50}$ damage levels. Similarly, as the buds deacclimated, the treatment temperature ranges were adjusted to successively higher starting and ending temperatures. Controls were similarly handled shoots that were kept at $4{ }^{\circ} \mathrm{C}$ with no exposure to the glycol freezing bath.

STATISTICAL ANALYSIS OF BUD COLD-HARDiness DATA AND ACCLIMATION/DEACCLIMATION. Bud cold-hardiness was defined as the temperature causing 50\% lethality among inflorescence primordia $\left(\mathrm{LT}_{50}\right)$. To calculate the $\mathrm{LT}_{50}$, nine data points (three shoots $\times$ three proximal buds) for each genotype/temperature were resampled ( $\mathrm{n}=9$ with replacement) 30 times (Manly, 1997). A sigmoidal regression was made of percent injury vs. temperature for each of the 30 sets of resampled data, and the 30

Table 2. Mean temperatures causing 50\% lethality $\left(\mathrm{LT}_{50}\right)$ of flower-bud cold-hardiness for field-grown blueberry plants in 2006-2007 and 20072008 based on sigmoidal regression of bracketed freeze/thaw damage evaluations and 30× bootstrap resampling.

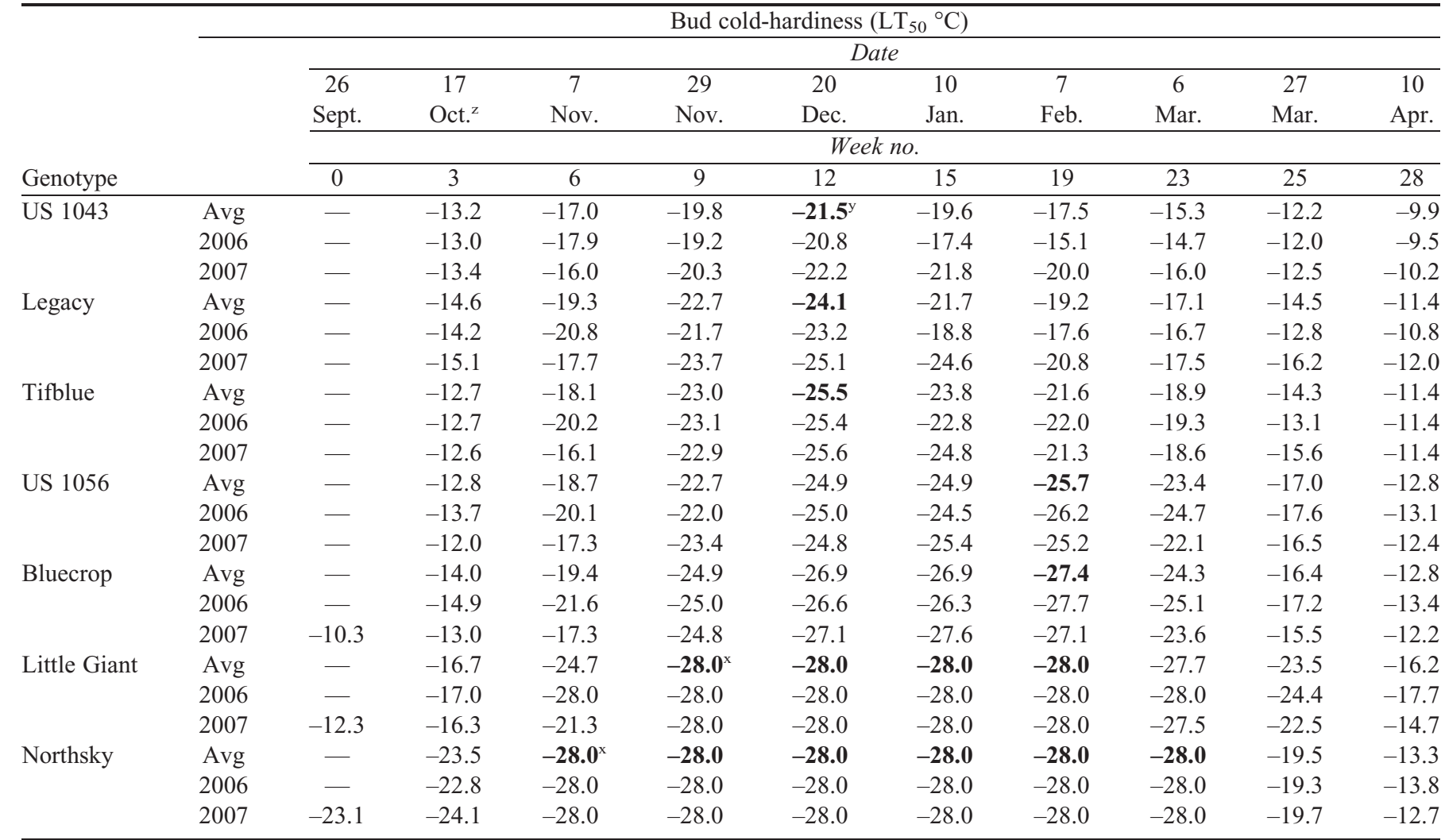

${ }^{\mathrm{z}}$ Average of dates sampled in 2006 and 2007. Actual dates did not deviate more than $\pm 1 \mathrm{~d}$.

yTemperatures on bold type represent $\mathrm{LT}_{50}$ minima of the 2-year averages.

${ }^{\mathrm{x}}-28{ }^{\circ} \mathrm{C}$ was the lowest value the freezing assay could achieve. 
resulting values of $\mathrm{LT}_{50}$ (and their lower and upper confidence limits) were averaged to obtain bootstrap $\mathrm{LT}_{50}$ estimates for each evaluation date. The $\mathrm{LT}_{50}$ estimates at each week of acclimation/ deacclimation were compared among genotypes by analysis of covariance (Milliken and Johnson, 2002). These estimates were also used to derive quadratic models of the relationship between $\mathrm{LT}_{50}$ and week of acclimation/deacclimation for each genotype.

Bud DeVelopment EVAluations. At each sampling for coldhardiness, five shoots with five to eight floral buds were evaluated for the stage of bud opening. Stages of flower-bud opening were ranked on the scale of 1 to 7 (Spiers, 1978) with 1 representing a stage with no visible swelling and 7 representing a stage at which corollas had completely expanded and dropped. Bud stages were recorded for each sampling date, and from this, a weighted average bud score was calculated.

\section{Results}

COMPARISON OF BUD COLD-HARDINESS DURING ACCLIMATION AND DEACCLIMATION. In the 2006-2007 season, we began sampling shoots in mid-October. In 2007-2008, we began sampling in late September for three cold-hardy selections and mid-October for the remaining selections. Sampling continued through early April in both years. Winter 2006-2007 was a colder winter with monthly averages of $24.1,18.5,12.6,10.6,5.6,3.4,-2.8,6.2$, and $10.2^{\circ} \mathrm{C}$ for the months of September through April (U.S. National Oceanic and Atmospheric Administration, 2010) (Fig. 1). Week 7 (14 Nov.) saw a spike in weekly average temperature to $15.3{ }^{\circ} \mathrm{C}$ followed by moderate temperatures $\left(6.3^{\circ} \mathrm{C}\right)$ through Week $16(17$ Jan.). Temperatures dropped steadily to $-4.8{ }^{\circ} \mathrm{C}$ in Week 19 (7 Feb.), which was the coldest week of the winter. Temperatures then increased fairly steadily throughout the remainder of the winter. By comparison, the winter of 2007-2008 was warmer with monthly averages of $24.0,20.6,17.2,7.0,2.8,2.0,2.7,7.0$, and $12.6^{\circ} \mathrm{C}$ for the months of September through April. Weeks 10 to 16 (3 Dec. to 17 Jan.) were cooler than in 2006-2007 with temperatures ranging from 2.0 to $5.0^{\circ} \mathrm{C}$. Week 17 (24 Jan.) was the coldest week of the winter with a weekly mean of $-0.6{ }^{\circ} \mathrm{C}$ and Week 19 (7 Feb.), the coldest week in the previous year, was virtually the mildest winter week in 2007-2008 with a temperature spike to $6.0^{\circ} \mathrm{C}$. After dropping back to $1.8^{\circ} \mathrm{C}$ in Week 20 (14 Feb.), temperatures showed a relatively steady climb throughout the remainder of the winter.

Despite 2007-2008 being a slightly warmer fall and winter, and Weeks 17 to 22 having divergent temperature patterns, the

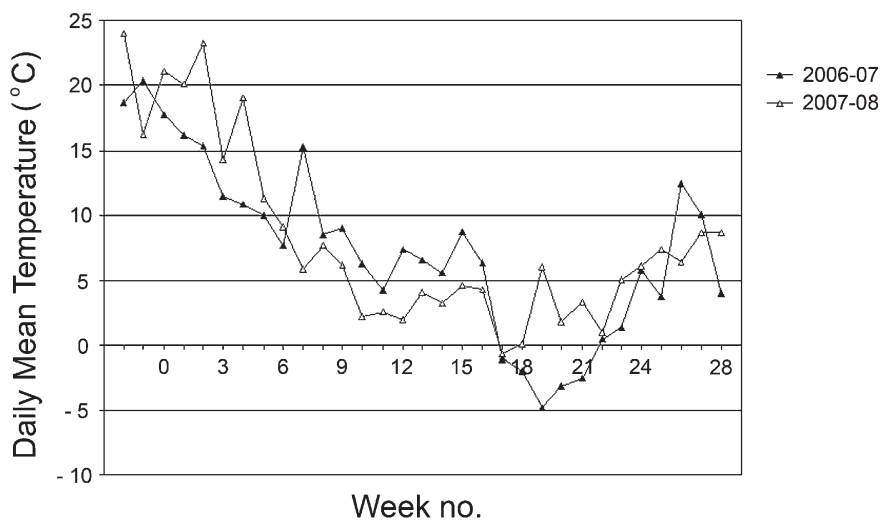

Fig. 1. Weekly mean temperatures in 2006-2007 and 2007-2008, Mount Holly, NJ. Week $0=$ last week of September; Week $28=$ second week of April.
$\mathrm{LT}_{50}$ values between years varied by less than $2{ }^{\circ} \mathrm{C}$ and, surprisingly, the 2007-2008 $\mathrm{LT}_{50}$ values were marginally lower (i.e., plants were more cold-hardy) in this milder winter than in 2006-2007 (Table 2).

The primary differences among our seven genotypes were: 1) differences in initial $\mathrm{LT}_{50}$ levels; 2) differences in the date at which maximum hardiness levels were achieved; 3 ) differences in the $\mathrm{LT}_{50}$ minimum values; and 4) differences in the period that acclimation was sustained. In general, in less cold-hardy types (US 1043, 'Legacy', and 'Tifblue'), maximum acclimation ( $\mathrm{LT}_{50}$ minima) was achieved by 20 Dec. and $\mathrm{LT}_{50}$ values increased (got warmer) through the remainder of the winter in a relatively linear manner (Fig. 2). More cold-hardy types (US 1056, 'Bluecrop', 'Northsky', and 'Little Giant') presented a broader range of responses.

Initial $\mathrm{LT}_{50}$ values (at 17 Oct.) ranged from $-12.8^{\circ} \mathrm{C}$ for US 1056 to $-23.5^{\circ} \mathrm{C}$ for 'Northsky' (Table 2). Most notably, 'Northsky' had an $\mathrm{LT}_{50}$ value significantly lower than the six other genotypes at this initial evaluation date.

US 1043, 'Legacy', 'Tifblue', US 1056, and 'Bluecrop' all reached maximum or near maximum cold acclimation (minimum $\mathrm{LT}_{50}$ ) by 20 Dec. (Week 12) with values of $-21.5,-24.1$, $-25.5,-24.9$, and $-26.9{ }^{\circ} \mathrm{C}$, respectively (Table 2; Fig. 2). For US 1043, 'Legacy', and 'Tifblue', this was in fact their lowest value. US 1056 and 'Bluecrop' continued to incrementally lower their $\mathrm{LT}_{50}$ values and reached their true minimums of cold acclimation levels (minimum $\mathrm{LT}_{50 \mathrm{~s}}$ ) by $7 \mathrm{Feb}$. with values of -25.7 and $-27.4{ }^{\circ} \mathrm{C}$, respectively. 'Little Giant' acclimated more quickly and achieved cold acclimation of $-28^{\circ} \mathrm{C}$ or below $\left(-28{ }^{\circ} \mathrm{C}\right.$ was the lowest value we could measure) by $29 \mathrm{Nov}$. (Week 9) and sustained $\mathrm{LT}_{50}$ values below $-28{ }^{\circ} \mathrm{C}$ for another 10 weeks (through Week 19). Similarly, 'Northsky' acclimated to an $\mathrm{LT}_{50}$ of $-28^{\circ} \mathrm{C}$ or below by 7 Nov. (Week 6) and sustained $\mathrm{LT}_{50}$ values below $-28{ }^{\circ} \mathrm{C}$ for another 17 weeks (through Week 23 ).

To facilitate statistical analysis and to allow conservative comparison with the other genotypes, the $\mathrm{LT}_{50}$ values of 'Little Giant' and 'Northsky' were taken to be $-28.0^{\circ} \mathrm{C}$ if a $50 \%$ damage level could not be bracketed during the assays using achievable temperatures. For further perspective, however, when percent damage to flower buds of 'Little Giant' and 'Northsky' (subjected to $-28^{\circ} \mathrm{C}$ assay temperatures) was evaluated and averaged across Weeks 12, 15, and 19 (20 Dec., 10 Jan., and 7 Feb.) and across both years of evaluation, they were observed to have only $18 \%$

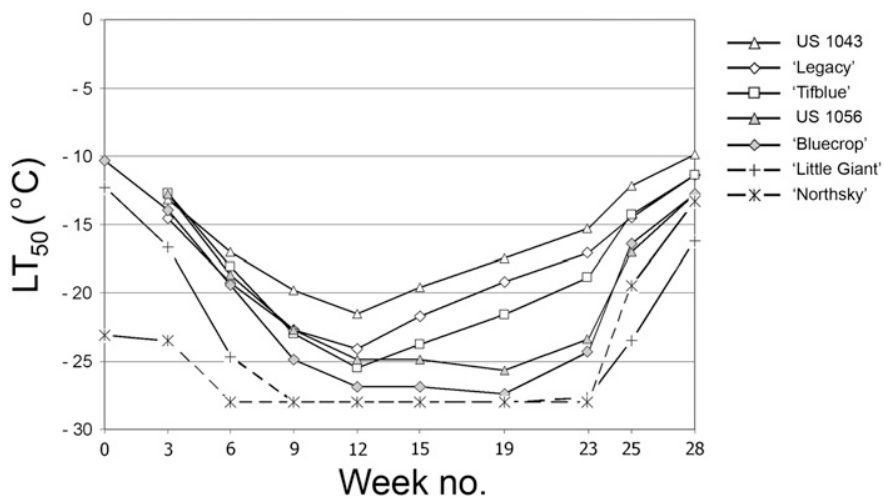

Fig. 2. Bud cold-hardiness values [temperature causing $50 \%$ lethality $\left(\mathrm{LT}_{50}\right)$ ] of blueberry genotypes averaged across 2006-2007 and 2007-2008 seasons. Dashed lines indicate segments of uncertainty because- $28{ }^{\circ} \mathrm{C}$ was the lowest value the freezing assay could achieve. 
and $17 \%$ damage, respectively. This suggests that their true $\mathrm{LT}_{50}$ values were considerably lower.

The less cold-hardy selections, US 1043, 'Legacy', and 'Tifblue', after reaching their $\mathrm{LT}_{50}$ minima at 20 Dec. (Week 12), started deacclimation in a fairly linear manner. In both years, the environmental mean temperatures for the next 4 weeks (27 Dec. to 17 Jan.) were not significantly different from Week 12 , and it was an additional 3 weeks to the coldest week in 20062007 and 1 additional week to the coldest week in 2007-2008.

In both years, the four cold-hardy selections sustained their acclimation to temperatures of $-25{ }^{\circ} \mathrm{C}$ or colder for longer intervals. 'Bluecrop' and US 1056 both sustained their acclimation through 7 Feb. (Week 19), which was the coldest week in 2006-2007 but was the mildest winter week in 2007-2008. 'Little Giant' and 'Northsky' had no $\mathrm{LT}_{50}$ values higher (warmer) than $-25{ }^{\circ} \mathrm{C}$ until 27 Mar. (Week 25).

BUD DEVELOPMENT OBSERVATIONS. Bud development rankings essentially followed $\mathrm{LT}_{50}$ values with rankings (in descending order, i.e., from greatest to least swell) as follows: 'Legacy', US 1043, 'Tifblue', US 1056, 'Bluecrop', 'Northsky', and 'Little Giant' (Table 3). Bud swell and $\mathrm{LT}_{50}$ values were highly correlated with an $r=0.85$ ( $P<0.001)$. US 1043 and 'Legacy' initiated bud swell from Week 15 onward and were consistently further advanced. 'Tifblue' initiated bud swell 10 weeks later and

Table 3. Averaged 2-year scores for stage of flower bud development of field-grown plants of blueberry genotypes over a 28 -week interval in 2006-2007 and 2007-2008.

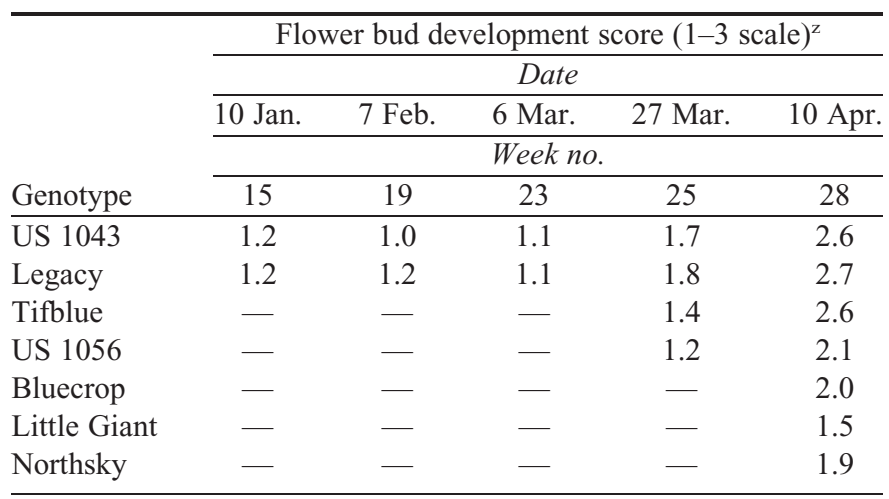

${ }^{\mathrm{z}}$ Stage of bud development (Spiers, 1978): 1 = no visible swelling; 2 = visible swelling of bud, and green tip visible; 3 = bud scales separated, and apices of flowers visible. Values are reported only after bud swell started (i.e., values $>1$ ). by the last date (10 Apr.), had bud swell comparable to US 1043 and 'Legacy'. US 1056 initiated at the same time as 'Tifblue' but had less development at each date. 'Bluecrop', 'Little Giant', and 'Northsky' all exhibited no bud swell until 10 Apr. Bud swell values greater than 1.5 did not occur until 27 Mar., and these values corresponded to $\mathrm{LT}_{50}$ values warmer than $-17^{\circ} \mathrm{C}$.

Modeling of aCCLIMATIOn/deACClimation. Quadratic models were used to allow statistical comparisons of behavior across the entire experimental period and to permit estimation of parameters related to acclimation and deacclimation behavior. Models showed significant differences between genotypes at critical dates across the experimental period. Because the quadratic model fits the data to a symmetric smoothed curve, it does not recognize plateaus, and thus the $\mathrm{LT}_{50}$ minima estimated from the quadratic model varied in some cases from the raw data values (Table 4 vs. Table 2). For example, the quadratic model places the $\mathrm{LT}_{50}$ minima for 'Bluecrop' and US 1056 at approximately Week 15 in the middle of their plateau period, making their $\mathrm{LT}_{50}$ minima appear to be earlier than the raw data show. This is less the case for US 1043, 'Legacy', and 'Tifblue', which have no plateaus in the raw data. Despite this shortcoming, the modeling has value in being able to make predictive estimations for genotypes such as 'Little Giant' and 'Northsky' whose midwinter values could not be measured (Table 4).

The quadratic models of the general form, $\mathrm{LT}_{50}=\mathrm{a}+\mathrm{bx}+$ $c x^{2}$, describe bud cold-hardiness ( $\mathrm{LT}_{50}$ values) as a function of weeks $(x)$ of acclimation/deacclimation (Table 5). In these models, "a" is a compensation factor related to the initial $\mathrm{LT}_{50}$ for each selection. The " $b$ " coefficient is a relative indication of when the $\mathrm{LT}_{50}$ minimum will be reached in the modeled equation, wherein lower values equate to an earlier date to reach minimum $\mathrm{LT}_{50}$. The coefficient " $\mathrm{c}$ " is a relative measure of rates of acclimation/deacclimation, wherein a lower value indicates a slower rate.

Thus, among these genotypes, the modeled rates of acclimation/deacclimation from fastest to slowest among selections were 'Bluecrop', US 1056, 'Tifblue', 'Little Giant', 'Legacy', 'Northsky', and US 1043 with the "c" coefficient values covering a range from 0.0874 ('Bluecrop') to 0.0543 (US 1043). The importance of any given rate should be considered vs. the corresponding $\mathrm{LT}_{50}$ minimum value. For most material, high (warm) $\mathrm{LT}_{50}$ minima equated to lower acclimation/deacclimation rates, and conversely low (cold) $\mathrm{LT}_{50}$ minima equated to higher rates of acclimation and deacclimation. This is logical because the more a genotype has to acclimate, the faster it might

Table 4. Comparisons of estimated mean temperatures causing 50\% lethality $\left(\mathrm{LT}_{50}\right)$ for blueberry genotypes across 2 years $(2006-2007$ and 2007-2008) for critical dates as derived from a quadratic model.

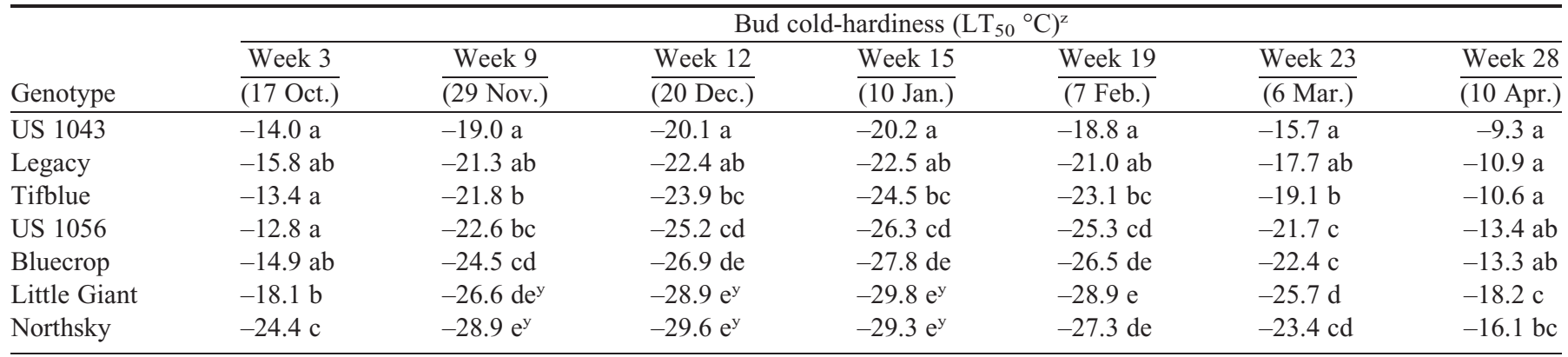

${ }^{\mathrm{z}}$ Modeled values are reported only for dates where measurements were actually taken (e.g., not for Week 13, the modeled regression minimum for 'Northsky'; see Table 5 and Fig. 1). Mean separation among genotypes within columns determined by $95 \%$ fiducial confidence limits.

${ }^{y}-28{ }^{\circ} \mathrm{C}$ was the lowest value the freezing assay could achieve. 
be expected to acclimate to reach its critical $\mathrm{LT}_{50}$ by midwinter. Considering this principle, 'Little Giant' and 'Northsky' were atypical among the genotypes we examined. 'Northsky' had a low acclimation/deacclimation rate but still achieved the lowest $\mathrm{LT}_{50}$ minima among our genotypes. 'Little Giant' had an approximate average rate but had the second lowest $\mathrm{LT}_{50}$ minima. These selections reached their $\mathrm{LT}_{50}$ minima in similar ways. 'Northsky' started at a significantly lower initial $\mathrm{LT}_{50}$ value in October and thus could reach its $\mathrm{LT}_{50}$ minima even with a relatively low acclimation rate. 'Little Giant' similarly started out with an initial $\mathrm{LT}_{50}$ significantly lower than three of our genotypes and had the second lowest rank, and thus although its acclimation rate was approximately equal to the average rate across genotypes, it could still reach a very low $\mathrm{LT}_{50}$ minima. 'Bluecrop' among widely adapted horticultural types had perhaps the best (most desirable) acclimation/deacclimation process and did so by starting at an initial $\mathrm{LT}_{50}$ value only slightly lower than average but having the highest rate of acclimation/deacclimation and starting deacclimation at a relatively late date.

The quadratic models are notable in that they show that both 'Northsky' and 'Little Giant' reached comparably low $\mathrm{LT}_{50}$ minima but did so at different times; 'Northsky' with a relatively slow rate of acclimation, but low initial $\mathrm{LT}_{50}$, did so at 27 Dec. (Week 13) and 'Little Giant' with a much more rapid acclimation rate, but higher initial $\mathrm{LT}_{50}$, did so at the relatively later date of 29 Jan. (Weeks 17-18) (Table 5). 'Little Giant' and 'Northsky' were acclimated to $-28^{\circ} \mathrm{C}$ or less for 10 and 23 weeks, respectively, and both had $\mathrm{LT}_{50}$ values below $-24{ }^{\circ} \mathrm{C}$ for fully 17 weeks. Notably, their acclimation/deacclimation curves were temporally displaced with 'Northsky' both acclimating and deacclimating earlier than 'Little Giant' (Fig. 3).

\section{Discussion}

One of the most valuable insights to come from this study is the observation that most genotypes essentially reached their $\mathrm{LT}_{50}$ minimum by late December and from that point followed one of two divergent paths. Some types immediately began to slowly deacclimate, although mean environmental temperatures continued to decrease. In contrast, others maintained their hardiness levels for extended periods. The retention or non-retention of cold-hardiness appeared only mildly related to germplasm composition. US 1043, 'Legacy', and 'Tifblue' all began to deacclimate after reaching their $\mathrm{LT}_{50}$ minima. These genotypes all have southern-adapted germplasm in their backgrounds but have widely diverse compositions. 'Tifblue' is $100 \% \mathrm{~V}$. ashei; 'Legacy' is 73\% V. corymbosum, 2\% V. angustifolium, and 25\% $V$. darrowii; and US 1043 is a complex hybrid comprised of six different species including $V$. constablaei. $V$. constablaei in previous studies was found to be extremely cold-hardy (Rowland et al., 2005). Additionally, the effect of $V$. constablaei germplasm in promoting cold-hardiness and late deacclimation has strong genetic effects such that 'Little Giant', which is $50 \% \mathrm{~V}$. constablaei and $50 \% \mathrm{~V}$. ashei, has cold-hardiness superior to all other genotypes tested, except for 'Northsky'. The early deacclimation

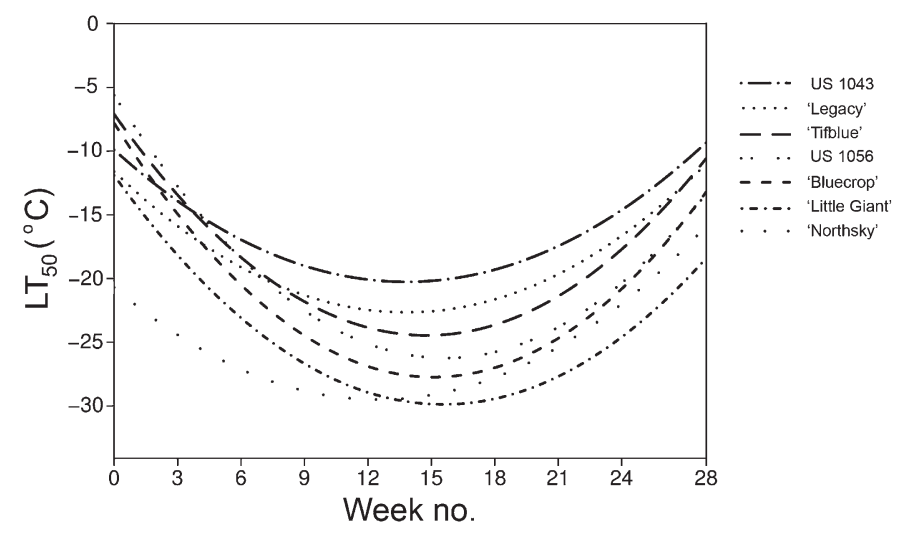

Fig. 3. Quadratic acclimation/deacclimation models of bud cold-hardiness [temperature causing $50 \%$ lethality $\left(\mathrm{LT}_{50}\right)$ ] of field-grown plants of blueberry genotypes across 2 years (2006-2007 and 2007-2008).

of US 1043 shows that by the second generation of crossing, and dependent on the parents used, the effect of $V$. constablaei can be quantitatively diluted and deacclimation behavior similar to the most cold-sensitive southern selections may result.

Conversely, it is valuable to know that hybrids of similar derivation (US 1056) may have acclimation/deacclimation profiles and cold-hardiness approaching that of 'Bluecrop' while still being composed theoretically of greater than $50 \%$ coldsensitive germplasm. US 1056 paralleled the acclimation and deacclimation of 'Bluecrop' and had an $\mathrm{LT}_{50}$ minimum that was only $1.4{ }^{\circ} \mathrm{C}$ warmer than that of 'Bluecrop'. Thus, superior coldhardiness and the ability to maintain acclimation are selectable factors given sufficient care in choice of parents and in evaluation of the resultant offspring under stringent field conditions.

'Northsky' was a notable genotype, because it acclimated early, was very cold-hardy, and had a significantly lower $\mathrm{LT}_{50}$ value than all other genotypes at the beginning of the experiment. The $\mathrm{LT}_{50}$ of 'Northsky' suggests that its acclimation is regulated differently, both qualitatively and quantitatively, with respect to daylength as compared with the other cultivars. 'Northsky' is a low-statured, spreading plant with the largest contribution of $V$. angustifolium germplasm among our genotypes $(27 \%)$. It is likely that much of the acclimation behavior of 'Northsky' is influenced by this lowbush germplasm contribution. Among highbush cultivars, Bittenbender and Howell (1975) found an $\approx 1.25: 1$ relative influence of photoperiod vs. air temperature on cold-hardiness. It seems likely that this 
relative influence of photoperiod is stronger in 'Northsky', and by extension, it may be hypothesized that the same behavior is likely to be seen in lowbush blueberry ( $V$. angustifolium). This possibility is best rationalized by recognizing that many genotypes of $V$. angustifolium evolved in northern climates where the growing season may be remarkably short and frost may be an occurrence during almost any month of the year. Brierley and Hildreth (1928), in evaluating cold damage of $V$. corymbosum, $V$. pennsylvanicum ( $=V$. angustifolium), and $V$. canadense $(=V$. myrtilloides $)$ in Minnesota, concluded that most winter damage was the result of immaturity coupled with an early onset of cold. In the 'Northsky' quadratic model, the predicted $\mathrm{LT}_{50}$ minimum occurred at 13 weeks (27 Dec.), almost exactly when a system with a greater response to daylength might be expected to have an inflection point. If we consider that our early deacclimators, US 1043, 'Legacy', and 'Tifblue', also had their inflection points at the same time point, it is legitimate to ask whether deacclimation (but not necessarily acclimation) in these additional genotypes might also be triggered more strongly by daylength than by temperature. Conversely, it can be posited that deacclimation/acclimation in 'Bluecrop' and US 1056 (and probably 'Little Giant') is more dependent on temperature.

A final thought regarding deacclimation must be a consideration of chilling-hour requirement. Once chilling-hour requirements are satisfied, plants are poised to deacclimate and flower. For southern-adapted genotypes such as 'Legacy' and 'Tifblue', chilling-hour requirements may be $600 \mathrm{~h}$ or fewer compared with that of northern-adapted types with chilling requirements of $1000 \mathrm{~h}$ or more. In this study, by late December, the low-chill genotypes (US 1043, 'Legacy', 'Tifblue') would have all been exposed to chill-hours in excess of their chilling requirements. Those having higher chilling requirements would not have reached this point until later in the winter. Nonetheless, it is notable that US 1043, 'Legacy', and 'Tifblue' began to deacclimate after late December despite environmental temperatures continuing to decrease.

\section{Conclusions}

Much progress has been made in understanding the underlying processes regulating vernalization, chilling, and cold responses. Rowland et al. (2005) demonstrated that levels and degradation of dehydrin proteins are closely correlated to midwinter cold-hardiness and deacclimation kinetics in blueberry. Most recently, Heo and Sung (2011), studying vernalization in Arabidopsis thaliana (L.) Heynh., resolved a temporal cascade of both sense and antisense RNA transcripts coded by promoter regions that regulate the adaptation process. Their results led them to hypothesize that the promoters themselves respond gradually to cold to produce vernalization effects that shift from reversible to irreversible as the winter proceeds. The processes regulating cold-hardiness in blueberry are probably under similar control.

As concerns about climate change increase, the knowledge of a germplasm's ability to tolerate temperature extremes and fluctuations, and the underlying processes controlling these traits, will prove increasingly valuable in creating new cultivars adapted to diverse environmental conditions. Blueberries possess a wide range of responses that can be used and selected to produce desirable acclimation and deacclimation processes.

\section{Literature Cited}

Arora, R., L.J. Rowland, J.S. Lehman, C.C. Lim, G.R. Panta, and N. Vorsa. 2000. Genetic analysis of freezing tolerance in blueberry (Vaccinium section Cyanococcus). Theor. Appl. Genet. 100:690-696.

Arora, R., L.J. Rowland, and G.R. Panta. 1997. Chill responsive dehydrins in blueberry: Are they associated with cold hardiness or dormancy transitions? Physiol. Plant. 101:8-16.

Ballington, J.R. 2001. Collection, utilization, and preservation of genetic resources in Vaccinium. HortScience 36:213-220.

Bittenbender, H.C. and G.S. Howell, Jr. 1975. Predictive environmental and phenological components of flower bud hardiness in highbush blueberry. HortScience 10:409-411.

Brierley, W.G. and A.C. Hildreth. 1928. Some studies on the hardiness of certain species of Vaccinium. Plant Physiol. 3:303-308.

Ehlenfeldt, M.K. 1994. The genetic composition and tetrasomic inbreeding coefficients of highbush blueberry cultivars. HortScience 29:1342-1345.

Ehlenfeldt, M.K., L.J. Rowland, E.L. Ogden, and B.T. Vinyard. 2007. Floral bud cold hardiness of Vaccinium ashei, V. constablaei, and hybrid derivatives and their potential for producing northern-adapted rabbiteye cultivars. HortScience 42:1131-1134.

Flinn, C.L. and E.N. Ashworth. 1994. Blueberry flower-bud hardiness is not estimated by differential thermal analysis. J. Amer. Soc. Hort. Sci. 119:295-298.

Gough, R.E. 1994. The highbush blueberry and its management. Food Products Press/Haworth Press, New York, NY.

Hancock, J.F. and J.H. Siefker. 1982. Levels of inbreeding in highbush blueberry cultivars. HortScience 17:363-366.

Hanson, E.J., S.F. Berkheimer, and J.F. Hancock. 2007. Seasonal changes in the cold hardiness of the flower buds of highbush blueberry with varying species ancestry. J. Amer. Pomol. Soc. 61:14-18.

Hanson, E.J. and J.F. Hancock. 1990. Highbush blueberry cultivars and production trends. Fruit Var. J. 44:77-81.

Heo, J.B. and S. Sung. 2011. Vernalization-mediated epigenetic silencing by a long intronic noncoding RNA. Science 331:76-79.

Manly, B.F.J. 1997. Randomization, bootstrap and Monte Carlo methods in biology. 2nd Ed. Chapman \& Hall, London, UK.

Milliken, G.A. and D.E. Johnson. 2002. Analysis of messy dataVolume III: Analysis of covariance. Chapman \& Hall/CRC, London, UK. Moore, J.N. 1993. The blueberry industry of North America. Acta Hort. 346:15-26.

Moore, J.N. 1994. The blueberry industry of North America. HortTechnology 4:96-102.

Muthalif, M.M. and L.J. Rowland. 1994. Identification of dehydrinlike proteins responsive to chilling in floral buds of blueberry (Vaccinium, section Cyanococcus). Plant Physiol. 104:1439-1447.

Rowland, L.J., E.L. Ogden, M.K. Ehlenfeldt, and R. Arora. 2008. Cold tolerance of blueberry genotypes throughout the dormant period from acclimation to deacclimation. HortScience 43:1970-1974.

Rowland, L.J., E.L. Ogden, M.K. Ehlenfeldt, and B. Vinyard. 2005. Cold hardiness, deacclimation kinetics, and bud development among 12 diverse blueberry (Vaccinium spp.) genotypes under field conditions. J. Amer. Soc. Hort. Sci. 130:508-514.

Sherman, W.B. and R.H. Sharpe. 1978. 'Beckyblue' blueberry. HortScience 13:61.

Spiers, J.M. 1978. Effect of stage of bud development on cold injury in rabbiteye blueberry. J. Amer. Soc. Hort. Sci. 103:452-455.

Trinka, D.L. 1996. Production trends in the cultivated blueberry industry of North America. Acta Hort. 446:33-36.

U.S. National Oceanic and Atmospheric Administration. 2010. National Climatic Data Center. 20 Oct. 2011. <http://www.ncdc.noaa. gov/oa/climate/stationlocator.html $>$.

Welling, A., P. Rinne, A. Vihera-Aarnio, S. Kontunen-Soppela, P. Heino, and E.T. Palva. 2004. Photoperiod and temperature differentially regulate the expression of two dehydrin genes during overwintering of birch (Betula pubescens Ehrh.). J. Expt. Bot. 55:507-516. 